\title{
Sineol dalam Minyak Kayu Putih sebagai Pelangsing Aromaterapi
}

Penulis

Afiliasi

\author{
Irmanida Batubara ${ }^{1,2 *}$, Irma Herawati Suparto ${ }^{1,2}$, Fiqa Annisa Rakhmatika ${ }^{1}$ \\ ${ }^{1}$ Departemen Kimia, FMIPA, Institut Pertanian Bogor, Indonesia \\ ${ }^{2}$ Pusat Studi Biofarmaka Tropika, LPPM, Institut Pertanian Bogor, Indonesia
}

Diterima 3 Maret 2016

Direvisi 12 Agustus 2016

Disetujui 29 Desember 2016

*Penulis korespondensi Irmanida Batubara Pusat Stusi Biofarmaka Tropika LPPM IPB

Jl. Taman Kencana No. 3, Bogor 16128

Email: ime@apps.ipb.ac.id

\section{ABSTRACT}

Cajuput is one of plants containing essential oil with cineole as a major component. This aim of study is to separate cineole in cajuput oil and to analyze its potency as slimming aromatherapy through in vivo assay. The essential oil was fractionated by column chromatography resulting 23 fraction (F1-F23). Cajuput oil, cineole, and F9 were analyzed by gas chromatograph-mass spectrometer, and the slimming aromatherapy potency was studied on white adult male Sprague-Dawley rats. Inhalation result of cineole showed that the average body weight of rats after 5 weeks treatment period was lower than that of the normal and the control groups which consumed high cholesterol feed. In conclusion, cineole is a compound that is potential in slimming aromatherapy.

\section{PENDAHULUAN}

Minyak kayu putih merupakan salah satu minyak atsiri yang diperoleh dari hasil penyulingan daun kayu putih. Minyak kayu putih ini memiliki manfaat yang cukup besar, baik bagi perekonomian masyarakat sekitar hutan maupun kegunaannya sebagai obatobatan, bahan insektisida, dan bahan wangi-wangian (Perum Perhutani 2004). Minyak ini juga memiliki bau dan khasiat yang khas. Khasiat utama dari minyak kayu putih adalah untuk melancarkan peredaran darah dengan melebarkan pori-pori kulit sehingga badan menjadi lebih hangat dan tidak akan mengganggu pernafasan kulit karena adanya sifat dari minyak kayu putih yang mudah menguap (Agoes 2010). Menurut Angela \& Davis (2010), minyak atsiri kayu putih dapat meningkatkan monosit dalam darah tikus setelah 15 hari diberi asupan oral minyak atsiri.

Komponen utama dari minyak kayu putih merupakan golongan terpenoid. Komponen terbesarnya merupakan 1,8-sineol yang merupakan senyawa monoterpena. Senyawa 1,8-sineol berperan sebagai antimikrob, antioksidan, kekebalan tubuh, analgesik, dan spasmolitik (Angela \& Davis 2010). Selain itu, senyawa 1,8-sineol juga berpotensi sebagai antiinflamasi (Juergens et al. 2003). Kajian mengenai tanaman kayu putih khususnya senyawa 1,8-sineol sebagai pelangsing aromaterapi belum dilakukan. Di sisi lain, menghirup minyak atsiri dapat memberi efek melangsingkan seperti menghirup 
grape fruit oil, kencur, sirih merah, lengkuas merah, dan sereh wangi ataupun menggemukkan seperti lavender oil dan minyak lempuyang (Shen et al. 2005a; Shen et al. 2005b Batubara et al. 2013; Batubara et al. 2014; Darusman et al. 2014; Batubara et al. 2015; Damayanti et al. 2015;). Oleh karena itu, penelitian ini bertujuan memisahkan 1,8-sineol yang terkandung dalam minyak atsiri kayu putih dan menganalisis potensinya sebagai pelangsing aromaterapi secara in vivo. Kandungan sineol dalam minyak atsiri kayu putih diharapkan berkhasiat sebagai pelangsing aromaterapi.

\section{METODE}

Bahan-bahan yang digunakan adalah minyak kayu putih dari Balai Penelitian Rempah dan Obat (Balittro), Bogor, pakan standar tikus, pakan kolesterol tinggi, propylthiouracil (PTU), akuades, aseton, $n$ heksana, metanol, dietil eter,etanol, etil asetat, kloroform, silika gel, dan pelat aluminium jenis silika gel $\mathrm{G}_{60} \mathrm{~F}_{254}$ dari Merck. Hewan uji yang akan digunakan pada penelitian ini adalah tikus putih jantan galur Sprague-Dawley yang diperoleh dari Balai Penelitian Ternak Bogor.

Metode penelitian yang dilakukan meliputi penentuan eluen terbaik dengan KLT, pemisahan dengan kromatografi kolom, identifikasi senyawa dengan GC-MS. Kemudian, inhalasi minyak atsiri, sineol, dan hasil pemisahan kromatografi kolom selama 5 minggu terhadap hewan uji yang telah melewati masa adaptasi selama 2 minggu. Bobot pakan tiap kelompok hewan uji ditimbang setiap hari dan bobot badan setiap hewan uji ditimbang setiap minggu. Pada minggu ke-5 setelah masa perlakuan, lemak hewan uji dikeluarkan dari tubuhnya untuk ditentukan deposit lemaknya. Seluruh prosedur pada hewan uji sudah disetujui oleh Komisi Etik Hewan IPB dengan nomor 042013 IPB.

Sebanyak 2,5 gram minyak kayu putih dipisahkan menggunakan pengemasan kolom sebanyak 40 dengan diameter $2 \mathrm{~cm}$ dan tinggi kolom $30 \mathrm{~cm}$. Saat pengemasan kolom, jumlah silika gel adalah 15-20 kali jumlah distilat dan perbandingan tinggi adsorban dan diameter kolom adalah 8:1. Minyak atsiri kayu putih dipisahkan dengan kolom kromatografi menggunakan elusi gradien (peningkatan kepolaran), eluen yang digunakan adalah eluen terbaik hasil KLT. Eluat ditampung setiap $3 \mathrm{~mL}$ dalam tabung reaksi yang telah diberi nomor kemudian diuji dengan KLT menggunakan eluen terbaik. Spot pemisahan dideteksi di bawah lampu UV dengan $\lambda 254 \mathrm{~nm}$ dan $366 \mathrm{~nm}$. Eluat yang memiliki $R_{f}$ dan pola KLT yang sama digabungkan sebagai satu fraksi.

Minyak atsiri kasar, fraksi 9, dan fraksi 13 yang diperoleh diinjeksikan ke dalam injektor GC-MS (Shimadzu-QP-5050A) dengan menggunakan kolom DB$5 \mathrm{MS}$ (dimensi $0.25 \mathrm{~mm} \times 30 \mathrm{~m}$ ) dan gas pembawa Helium dengan laju alir $42 \mathrm{~mL} /$ menit. Suhu injektor dan detektor sama, yaitu $250{ }^{\circ} \mathrm{C}$ sedangkan suhu kolom yang digunakan adalah suhu terprogram, yaitu diawali dengan $80^{\circ} \mathrm{C}$ ditahan selama 2 menit kemudian diubah perlahan-lahan dengan laju kenaikan suhu sebesar 5 ${ }^{\circ} \mathrm{C}$ /menit hingga suhunya mencapai $250{ }^{\circ} \mathrm{C}$ ditahan selama 5 menit. Kondisi spektrometer massanya adalah energi ionisasi $70 \mathrm{eV}$, mode ionisasinya adalah Electron Impact Ionisation (EI), split ratio: 25.0, dan area deteksinya adalah $40-500 \mathrm{~m} / \mathrm{z}$. Setiap puncak yang muncul dalam kromatogram ion total diidentifikasi dengan menganalisis hasil spektum massa yang terdapat pada library index MS.

Uji aktivitas aromaterapi digunakan tikus putih jantan galur Sprague-Dawley yang sehat, berumur \pm 2.5 bulan dengan bobot kisaran $167 \mathrm{~g}$, dan berjumlah 30 ekor. Setiap 2 ekor ditempatkan dalam satu kandang dengan ukuran $20 \times 20 \times 30 \mathrm{~cm}^{3}$. Proses adaptasi kondisi fisiologis, nutrisi, dan lingkungan tikus tersebut dilakukan selama 2 minggu. Semua kelompok tikus diberi pakan standar tikus dengan dosis $20 \mathrm{~g} /$ ekor/hari dan diberi minum akuades secara ad libitum. Masa adaptasi dilakukan dengan tujuan untuk pengenalan lingkungan baru bagi tikus yang akan digunakan sebagai hewan uji.

Uji inhalasi minyak atsiri kasar, sineol, dan fraksi lain yang mengandung sineol dalam jumlah sedikit dari minyak atsiri kayu putih secara in vivo dilakukan berdasarkan pada modifikasi metode Batubara et al. (2013). Kelompok tikus yang dijadikan kontrol negatif (kelompok I) tetap diberi pakan standar tikus dengan dosis $20 \mathrm{~g} /$ ekor/hari dan diberi akuades secara ad libitum selama masa perlakuan, yaitu 5 minggu tanpa diinhalasi. Tikus-tikus yang diberi pakan kolesterol tinggi sebanyak $20 \mathrm{~g} / \mathrm{ekor} / \mathrm{hari}$ dikelompokkan menjadi 4 kelompok, yaitu kelompok II, III, IV, dan V serta air minum akuades yang ditambahkan PTU $0.1 \%$ secara ad libitum. Masing-masing kelompok tersebut terdiri atas 6 ekor tikus. Kelompok II tidak diberikan perlakuan aromaterapi, sedangkan kelompok III, IV, dan V diberi perlakuan aromaterapi selama 5 minggu. Kelompok III diinhalasi minyak atsiri kasar kayu putih, kelompok IV 
diinhalasi sineol, dan kelompok $\mathrm{V}$ diinhalasi fraksi lain yang mengandung sineol dalam jumlah sedikit, masingmasing kelompok diinhalasi dengan dosis $0.1 \%$. Bobot badan masing-masing tikus dari semua kelompok ditimbang seminggu sekali. Jumlah feses dan urin dari semua kelompok tikus ditimbang setiap tiga hari sekali.

Pada minggu ke-5 setelah masa perlakuan, masing-masing tikus dari setiap kelompok perlakuan, yaitu kelompok I, II, III, IV, dan V dipuasakan selama 12 jam. Tikus disedasi (pembiusan) dengan cara menyuntikkan ketamin ( $80 \mathrm{mg} / \mathrm{kg}$ bobot badan) dan xilazin $(10 \mathrm{mg} / \mathrm{kg}$ bobot badan) secara intraperitoneal. Setelah tikus tidak sadarkan diri kemudian proses pembedahan dilakukan. Lemak pada bagian perut kanan dan kiri serta bagian testis kanan dan kiri dikeluarkan. Keadaan lemak tersebut diamati, ditimbang bobotnya, dan ditentukan persentasenya terhadap bobot badan tikus masing-masing. Data bobot pakan yang dikonsumsi, bobot feses dan urin yang dihasilkan, bobot badan serta bobot deposit lemak hewan uji yang diperoleh dianalisis dengan metode rancangan acak lengkap (RAL) dan Analysis of Variance (ANOVA) pada taraf kepercayaan 95\% ( $\alpha=$ 0.05 ) dilanjutkan dengan Duncan's multiple range test menggunakan SPSS 16.

\section{HASIL DAN PEMBAHASAN}

Minyak atsiri kayu putih yang digunakan berwarna kuning terang dengan Kadar sineol sebesar 67.74\% serta memiliki wangi yang khas seperti minyak kayu putih. Hal ini sesuai dengan SNI 06-3954-2006 (BSN 2006) yang menyatakan bahwa minyak atsiri kayu putih berwarna kekuningan, kadar sineol yang terkandung lebih besar dari $65 \%$ dan memiliki wangi yang khas seperti minyak kayu putih pada umumnya. Selain itu juga terkandung $\alpha$-pinena dan o-simena dengan kadar sekitar 7\% (Tabel 2). Kandungan sineol pada minyak kayu putih yang digunakan jauh lebih besar dari pada kandungan sineol yang terdapat pada minyak kayu putih yang digunakan oleh Muchtaridi et al. (2016) yang hanya sebesar $22.45 \%$.

Minyak atsiri kayu putih dipisahkan dengan kromatografi kolom menggunakan eluen terbaik dengan sistem step gradient (peningkatan kepolaran). Eluen yang digunakan berupa $n$-heksana murni, campuran antara $n$-heksana dan kloroform dengan perbandingan 9:1 sampai 1:9, kloroform murni, campuran antara kloroform dan etil asetat dengan perbandingan 9:1 sampai 1:9 serta etil asetat murni dan dihasilkan sebanyak 23 fraksi (Tabel 1). Fraksi 9, 10, 11, dan 13 memiliki rendemen terbanyak sebesar $4.46 \%, 4.25 \%, 4.23 \%$, dan $2.63 \%$ dengan jumlah noda

Tabel 1. Hasil Fraksinasi minyak atsiri kayu putih dengan teknik elusi gradien kromatografi kolom

\begin{tabular}{cccc}
\hline Fraksi ke- & Jumlah noda pada KLT & Bobot (g) & Rendemen (\%) \\
\hline 1 & 1 & 0.0129 & 0.56 \\
2 & 1 & 0.0152 & 0.66 \\
3 & 1 & 0.0138 & 0.59 \\
4 & 1 & 0.0240 & 1.04 \\
5 & 2 & 0.0414 & 1.79 \\
6 & 2 & 0.0285 & 1.23 \\
7 & 6 & 0.0442 & 1.91 \\
8 & 4 & 0.0366 & 1.58 \\
9 & 4 & 0.1035 & 4.46 \\
10 & 2 & 0.0985 & 4.25 \\
11 & 3 & 0.0981 & 4.23 \\
12 & 3 & 0.0462 & 1.99 \\
13 & 5 & 0.0610 & 2.63 \\
14 & 5 & 0.0260 & 1.12 \\
15 & 4 & 0.0200 & 0.86 \\
16 & 4 & 0.0340 & 1.47 \\
17 & 2 & 0.0104 & 0.45 \\
18 & 2 & 0.0127 & 0.55 \\
19 & 1 & 0.0142 & 0.61 \\
20 & 2 & 0.0225 & 0.97 \\
21 & 2 & 0.0260 & 0.01 \\
22 & 1 & 0.0223 & 0.96 \\
23 & 3 & 0.0155 & 0.67 \\
\hline
\end{tabular}


pada fraksi 9 sebanyak 4 noda, fraksi 10 sebanyak 2 noda, fraksi 11 sebanyak 3 noda, dan fraksi 13 sebanyak 5 noda. Pada keempat fraksi tersebut, sineol diduga berada pada fraksi 9 . Fraksi 9 dan 13 dianalisis lebih lanjut dengan GC-MS untuk diindentifikasi komponen kimianya dan diuji aktivitasnya secara in vivo. Dengan menggunakan kromatografi gasspektrometri massa, diketahui bahwa fraksi 9 dan 13 memiliki kadar 1,8-sineol sebesar 5.70\% dan 1.25\% (Tabel 2). Pada fraksi 9, komponen lain yang teridentifikasi pada minyak atsiri kayu putih tidak ditemukan kembali, namun terdapat komponen lain yaitu $\alpha$-terpineol dan viridiflorol dengan kadar sebesar 9.13\% dan $11.77 \%$. Pada fraksi 13 menunjukkan terdapat 4 komponen utama yang teridentifikasi yaitu sineol (1.25\%), diisooktil adipat (6.48\%), Cis-1,3,3trimetil-2-oxabisiklo [2.2.2] oktan-5-ol (3.69\%), dan 4,4,8-trimetiltrisiklo [6.3.1.0(1,5)] dodekana-2,9-diol (2.21\%). Struktur senyawa dominan pada minyak kayu putih dapat dilihat pada Gambar 1.

Uji in vivo dari minyak atsiri kasar, sineol, dan fraksi 9 dilakukan terhadap tikus putih jantan galur Sprague-Dawley selama 5 minggu dengan konsentrasi $0.1 \%$. Bobot badan tikus diukur satu minggu sekali dan dipantau perubahannya akibat perlakuan. Hasilnya ditunjukkan pada Gambar 2. Berdasarkan gambar tersebut, diketahui bahwa semua kelompok tikus memiliki peningkatan bobot badan di setiap minggunya. Namun, pada minggu ke-1 terjadi penurunan bobot badan yang dikarenakan tikus masih beradaptasi dengan pakan kolesterol tinggi yang diberikan. Pada akhir masa perlakuan terlihat bahwa kelompok IV memiliki rerata bobot badan paling rendah dibandingkan dengan kelompok lainnya.

Tabel 3 menjelaskan rerata bobot badan tikus pada awal dan akhir perlakuan. Kelompok IV memiliki bobot yang paling rendah (199.60 g) dan berbeda signifikan dibandingkan kelompok lainnya dengan nilai

Tabel 2. Konsentrasi senyawa dominan dalam minyak atsiri kasar, F9, dan F13

\begin{tabular}{llccc}
\hline \multicolumn{1}{c}{ Golongan } & \multicolumn{1}{c}{ Senyawa } & Minyak kayu putih (\%) & F9 (\%) & F13 (\%) \\
\hline Monoterpena & $\alpha$-pinena & 7.83 & - & - \\
& B-pinena & 4.18 & - & - \\
& m-simena & 2.06 & - & - \\
& Limonena & 2.40 & - & - \\
& o-simena & 7.45 & - & - \\
& Cis-1,3,3-trimetil-2-oxabisiklo [2.2.2] oktan-5-ol & - & - & 3.69 \\
\hline Monoterpena & 1.8-sineol & 67.74 & 5.70 & 1.25 \\
alkohol & $\alpha$-terpineol & - & 9.13 & - \\
\hline Seskuiterpena & Viridiflorol & - & 11.77 & - \\
& 4,4,8-trimetiltrisiklo[6.3.1.0(1,5)] dodekana-2,9- & - & - & 2.21 \\
& diol & & & \\
\hline Polimer & Diisooktil adipat & - & - & 6.48 \\
\hline
\end{tabular}<smiles>C=C1CCC2CC1C2(C)C</smiles><smiles></smiles>
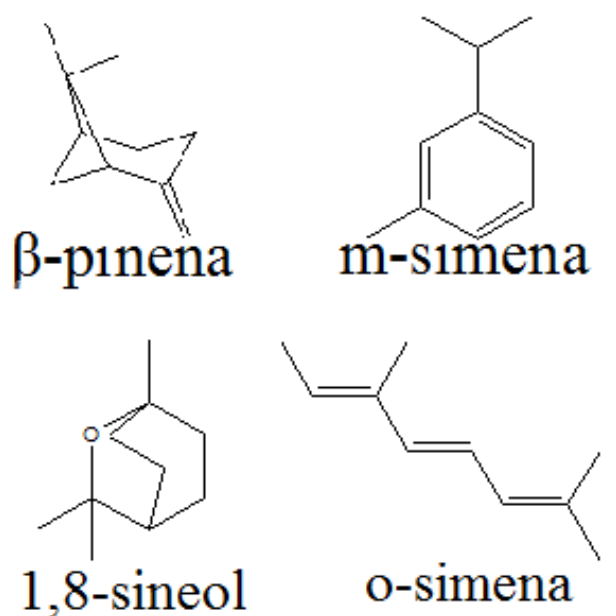

Gambar 1. Senyawa yang terkandung dalam minyak atsiri kayu putih 
p<0.05. Berdasarkan hal tersebut, inhalasi sineol berpotensi menurunkan bobot badan hewan uji. Efek penurunan bobot badan dapat disebabkan oleh tergertaknya jaringan adipose coklat (Nurcholis et al. 2013). Tabel 4 menunjukkan konsumsi pakan tikus setiap minggu selama masa perlakuan. Berdasarkan hasil tersebut, terlihat bahwa konsumi pakan tikus pada kelompok II, III, IV, dan V tidak berbeda signifikan, namun pada kelompok I menunjukkan hasil yang berbeda signifikan dengan $p<0.05$. Terlihat bahwa, kelompok I memiliki konsumsi pakan terendah dibandingkan dengan kelompok lainnya, yaitu sebesar 138.83 g. Jika dilihat, kelompok IV tidak menunjukkan hasil yang berbeda signifikan pada konsumsi pakan namun pada hasil penentuan bobot badan justru menunjukkan hasil yang sebaliknya. Hal ini menunjukkan bahwa inhalasi sineol tidak mempengaruhi konsumsi pakan namun dapat menurunkan bobot badan tikus.

Penentuan bobot deposit lemak dianalisis pada minggu akhir perlakuan setelah tikus dipuasakan selama 12 jam. Hasil yang didapatkan terlihat pada Tabel 4. Rerata bobot deposit lemak yang didapatkan pada setiap kelompok tidak menunjukkan hasil yang berbeda signifikan $(P>0.05)$. Hasil yang tidak berbeda siginifikan pada kelompok pakan kolesterol pada 5,

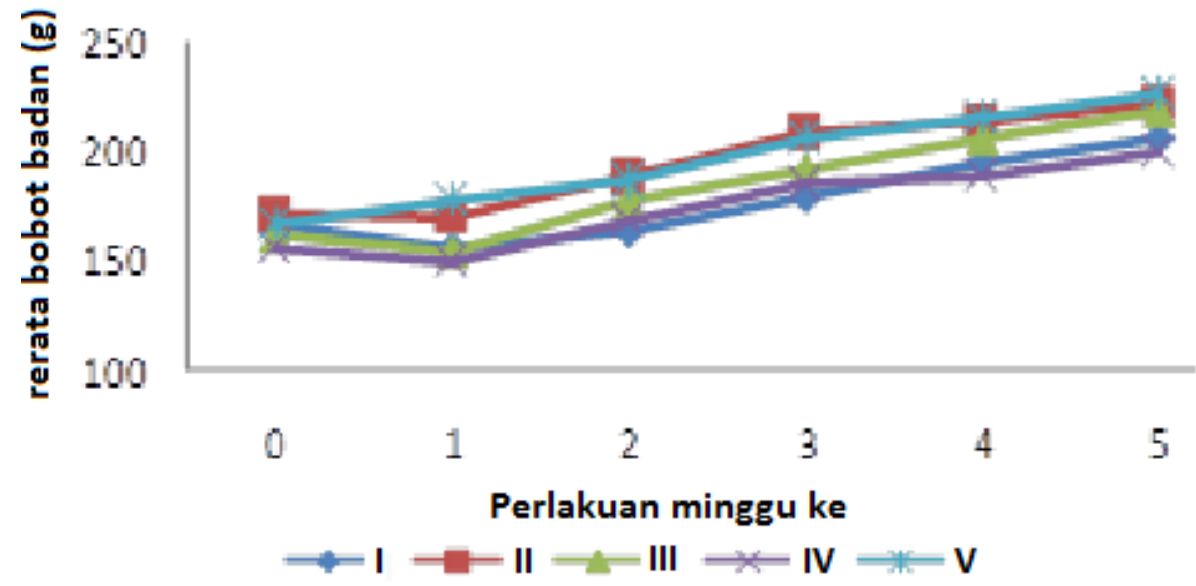

Gambar 2. Perubahan rerata bobot badan tikus tiap kelompok selama masa perlakuan

Tabel 3. Rerata bobot badan tikus pada awal dan akhir perlakuan

\begin{tabular}{llcc}
\multicolumn{1}{c}{ Kelompok } & $\begin{array}{c}\text { Bobot Awal (g) } \\
(\mathbf{p}>0.05)\end{array}$ & $\begin{array}{c}\text { Bobot Akhir (g) } \\
\text { ( } \mathbf{p}<0.05)\end{array}$ \\
\hline (I) Pakan Standar & $167.00 \pm 14.28^{\mathrm{a}}$ & $206.67 \pm 15.41^{\mathrm{b}}$ \\
(II) Tinggi Kolesterol (TK) & $170.67 \pm 12.54^{\mathrm{a}}$ & $222.50 \pm 13.56^{\mathrm{b}}$ \\
(III) TK + Minyak Atsiri & $161.40 \pm 14.22^{\mathrm{a}}$ & $219.00 \pm 12.66^{\mathrm{b}}$ \\
(IV) TK + Sineol & $155.80 \pm 8.52^{\mathrm{a}}$ & $199.60 \pm 15.53^{\mathrm{a}}$ \\
(V) TK + F9 & $167.00 \pm 14.55^{\mathrm{a}}$ & $226.83 \pm 19.80^{\mathrm{b}}$ \\
\hline
\end{tabular}

Angka yang diikuti oleh huruf superscripts yang sama tidak berbeda signifikan pada taraf uji ( $\mathrm{P}>0.05)$ (Duncan's multiple range test)

Tabel 4. Rerata bobot pakan tikus perminggu (g/ekor) selama masa perlakuan dan rerata bobot deposit lemak tikus

\begin{tabular}{lcc}
\multicolumn{1}{c}{ Kelompok } & $\begin{array}{c}\text { Jumlah pakan }(\mathrm{g}) \\
(\mathbf{p}<0.05)\end{array}$ & $\begin{array}{c}\text { Deposit lemak (g) } \\
(\mathbf{p}<0.05)\end{array}$ \\
\hline (I) Pakan Standar & $138.83 \pm 5.72^{\mathrm{b}}$ & $2.51 \pm 0.55^{\mathrm{a}}$ \\
(II) Tinggi Kolesterol (TK) & $157.73 \pm 1.17^{\mathrm{a}}$ & $3.20 \pm 0.60^{\mathrm{a}}$ \\
(III) TK + Minyak Atsiri & $163.54 \pm 0.95^{\mathrm{a}}$ & $3.80 \pm 0.60^{\mathrm{a}}$ \\
(IV) TK + Sineol & $160.79 \pm 1.27^{\mathrm{a}}$ & $3.44 \pm 0.59^{\mathrm{a}}$ \\
(V) TK + F9 & $162.31 \pm 1.10^{\mathrm{a}}$ & $4.01 \pm 0.60^{\mathrm{a}}$ \\
\hline
\end{tabular}

Angka yang diikuti oleh huruf superscripts yang sama tidak berbeda signifikan pada taraf uji ( $\mathrm{P}>0.05)$ (Duncan's multiple range test) 
dapat disebabkan karena dengan konsumsi kolesterol dan lemak lebih tinggi, maka energi berlebih yang dihasilkan akan terdeposit dalam bentuk lemak. Hal ini terbukti dari kencenderungan pada pakan standar yang memiliki bobot deposit lemak terendah. Ganong (2003) menyatakan bahwa pemberian PTU dapat menyebabkan terhambatnya hormon tiroid yaitu dengan mengurangi pengeluaran kolesterol dari sirkulasi sehingga terjadi peningkatan kolesterol dalam darah yang tertimbun dalam bentuk lemak.

\section{SIMPULAN}

Minyak atsiri kayu putih dipisahkan menggunakan teknik kromatografi untuk mendapatkan senyawa penyusunnya. Secara in vivo inhalasi sineol dapat berpotensi sebagai pelangsing aromaterapi tanpa mengurangi konsumsi pakan.

\section{DAFTAR PUSTAKA}

Agoes A. 2010. Tanaman Obat Indonesia. Jakarta (ID): Salemba Medika.

Angela ES, Davis WL. 2010. Immune-modifying and antimicrobial effects of eucalyptus oil and simple inhalation devices. Alternative Medicine Review. 15 (1):33-47.

[BSN] Badan Standarisasi Nasional. 2006. Minyak Kayu Putih. SNI 06-3954-2006. Jakarta.

Batubara I, Anggraeni A, Darusman LK. 2013. Inhalasi aroma temulawak terhadap bobot badan tikus. Jurnal Bahan Alam Indonesia. 8(3):187-191.

Batubara I, Suparto IH, Sadiah S, Matsuoka R, Mitsunaga T. 2013. The Effect of Zingiber zerumbet Essential Oils and Zerumbone Inhalation on Body Weight of Sprague Dawley Rat. Pakistan Journal of Biological Sciences. 16(19):1028-1033.

Batubara II, Assaat LD, Irawadi TT, Mitsunaga T, Yamauchi K. 2014. Effect Of Sniffing Of Kencur (Kaemferia Galangal) Essential Oils In Rats . Acta Horticulturae. (ISHS) 1023:123-127.

Batubara I, Suparto IH, Sadiah S, Matsuoka R, Mitsunaga T. 2015. Effects of Inhaled Citronella
Oil and Related Compounds on Rat Body Weight and Brown Adipose Tissue Sympathetic Nerve. Nutrients. 7(3):1859-1870.

Damayanti R, Batubara I, Suparto IH. 2015. Essential Oil of Red Galangal (Alpinia galanga (L) Willd) Rhizome as Slimming Aromatherapy. International Journal of Pharma and Biosciences. 6(1):(P)283-289.

Ganong WF. 2003. Buku Ajar Fisiologi Kedokteran Ganong Ed. 22. Jakarta (ID): EGC.

Darusman LK, Batubara II, Utami MR. 2014. Fractionation of active components from Piper of fragile essential oil as aromatherapy or antiobesity. Acta Horticulturae. (ISHS) 1023:23-28

Juergens UR, Dethlefsen U, Steinkamp G, Gillissen A, Repges R, Vetter H. 2003. Anti-inflammatory activity of 1.8-cineol (eucalyptol) in bronchial asthma: a double-blind placebo-controlles trial. Respiratory Medicine. 97:250-256.

Muchtaridi, Tjiraresmi A, Febriyanti R. 2016. Analysis of Active Compounds in Blood Plasma of Mice After Inhalation of Cajuput Essential Oil (Melaleuca laecadendron L.). Indonesian Journal of Pharmacy. 26(4):219-227.

Nurcholis W, Batubara I, Suparto IH, Sadiah S, Mitsunaga T. 2013. Pengaruh inhalasi aroma temulawak terhadap syaraf simpatik dan suhu jaringan adiposa coklat. Jurnal Bahan Alam Indonesia. 8(4):270-273

Perum Perhutani. 2004. Statistik Perum Perhutani 1999-2003. Jakarta (ID): Direksi Perum Perhutani.

Shen J, Niijima A, Tanida M, Horii Y, Maeda K, Nagai K. 2005a. Olfactory stimulation with scent of grapefruit oil affects autonomic nerves, lipolysis and appetite in rats. Neuroscience Letters. 380:289-294.

Shen J, Niijima A, Tanida M, Horii Y, Maeda K, Nagai K. 2005b. Olfactory stimulation with scent of lavender oil affects autonomic nerves, lipolysis and appetite in rats. Neuroscience Letters. 383:188-193. 